\title{
UTILITY OF SERUM ALLERGY TEST IN PATIENTS WITH CHRONIC URTICARIA
}

\author{
Bhattarai $\mathrm{S}^{1}$, Pradhan $\mathrm{K}^{2}$, Sharma $\mathrm{S}^{2}$, Pant $\mathrm{AD}^{3}$
}

ABSTRACT

\section{INTRODUCTION:}

Chronic urticaria $(\mathrm{CU})$ is a common skin disorder affecting $15-20 \%$ of the people in the general population. It is a frequent disease which presents with wheals, angiooedema or both and lasts for over six weeks or more.

\section{OBJECTIVES:}

To determine the etiology of IgE specific allergens in the causative of CU in the Nepalese population

\section{MATERIALS \& METHODS:}

A prospective cross sectional study was carried out between November 2014- October 2016 on all patients diagnosed as having CU. Blood samples were taken from all patients and asemiquantitative determination of IgE antibodies against a panel of individual allergens was done and data analyzed and interpreted in terms of numbers and percentages.

\section{RESULTS:}

Three hundred and fourteen patients were included in the study with 56\% (175) being female and 44\% (139) being male. The age of the patients ranged from 5 years to 84 years with a mean of $37.33 \pm 14.39$ years. The duration of the disease also ranged from 0.15 to 20 years in which $116(36.9 \%)$ patients presented with disease of less than 6 months duration while $163(51.9 \%)$ patients had the disease for more than 6 months.

Two hundred and seventy nine patients $(88.9 \%)$ showed a positive test to the allergens amongst which most were allergic to plants which included weeds and grass.

\section{CONCLUSION}

In patients with $\mathrm{CU}$ whenever possible it is advisable to send the patient for serum allergy test to determine the causative agent, the avoidance of which can help in the management of urticaria in troublesome patients.

KEYWORDS:Chronic Urticaria, Serum allergy test

1. Associate Professor, Department of Dermatology and Venereology, Kathmandu Medical College and Teaching Hospital, Kathmandu, Nepal

2. Medical Student, Kathmandu Medical College and Teaching Hospital, Kathmandu, Nepal

3. Associate Professor, Department of Pathology,Maharajgunj Medical Campus, Tribhuvan University Teaching Hospital, Maharajgunj, Kathmandu, Nepal

\author{
For Correspondence: \\ Dr Sabina Bhattarai \\ Associate Professor \\ Department of Dermatology and Venereology \\ Kathmandu Medical College and Teaching Hospital \\ Sinamangal, Nepal \\ Email:sabeenab@gmail.com
}




\section{INTRODUCTION}

Chronic urticaria $(\mathrm{CU})$ is a common skin disorder affecting $15-20 \%$ of the people in the general population. It is a frequent disease which presents with wheals, angiooedema or both and lasts for over six weeks or more.

$\mathrm{CU}$ can be classified into three clinical subgroups, spontaneous (80\%), physical (10\%) and special forms $(10 \%)$ based on its duration, frequency and causes. ${ }^{1}$

Multifactorial etiologies have been implicated in the causation of $\mathrm{CU}$, the autoimmune processes being the most common followed by intolerance to food or drugs and infectious diseases. ${ }^{2-4}$ Most patients with CU have no exogenous cause but for some it is extremely disabling. The search for correlating CU with different sources and trying to refrain from foods that are likely to implicate the disease is very demanding to few patients to cause an urticaria free life.

There are no prevalent studies on medline search to show the specific allergens which could implicate the causation of wheals in the Nepalese population using serum allergy test . Our study thusaimed to determine the causative etiology of $\mathrm{IgE}$ specific allergens in the causative of CU.

\section{MATERIALS \& METHODS}

Patient Inclusion:

A prospective cross sectional study was carried out between November 2014- October 2016 on all patients diagnosed as having CU. The study protocol and all the amendments were reviewed and approved. The demographic data regarding age, gender and duration of the disease were taken and patients with history of inducibleurticaria and other autoimmune diseases were excluded from the study .

The patients were advised to stop the antihistamine for 3 days prior to the serum allergy test and blood samples were taken after a written informed consent was given by all patients.

Laboratory Method:

RIDA AllergyScreen, manufactured by R-Biopharm AG in Germany, is an enzyme immunoassay done on a nitrocellulose membrane. It is used for semiquantitative determination of $\mathrm{IgE}$ antibodies against a panel of individual allergens. 250 microliters of serum is mixed with wash buffer, antibody, conjugate, and substrate for varying intervals respectively, for a total time of 130 minutes. Then, evaluation is done on the RIDA X-Screen with the help of software, and results are given in IU/ml. The test is valid when the background has disappeared and there is a strong positive control band.
Standard Panel 1 was used in our series to determine the causative allergens which includes 80 different allergens (Table 1)

\begin{tabular}{|c|c|c|c|}
\hline Allergen Group & English Name & Allergen Group & English Name \\
\hline \multirow{5}{*}{ Grass Mix GX1 } & Bermuda grass & \multirow{4}{*}{ Mold Mix MX1 } & Alternariaalternata \\
\hline & Maize & & \begin{tabular}{|l|} 
Cladosporiumherbarum \\
\end{tabular} \\
\hline & Rye & & $\begin{array}{l}\text { Cladosporiumcladosporoides } \\
\end{array}$ \\
\hline & Orchard grass & & Stemphylliumbotryosum \\
\hline & Timothy grass & \multirow{4}{*}{ Mold Mix MX2 } & Aspergillusfumigatus \\
\hline \multirow{4}{*}{ Tree Mix TX1 } & Alder & & Aspergillusniger \\
\hline & Birch & & Aspergillusflavus \\
\hline & Oak & & Aspergillusversicolor \\
\hline & Poplar & \multirow{3}{*}{ Mold Mix MX3 } & Penicilliumchrysogenum \\
\hline \multirow{4}{*}{ Tree Mix TX2 } & Acacia & & \begin{tabular}{|l|} 
Penicilliumnotatum \\
\end{tabular} \\
\hline & Eucalyptus & & Candida albicans \\
\hline & Mesquite & \multirow{3}{*}{ Food Mix FX1 } & \begin{tabular}{|l|} 
Egg white \\
\end{tabular} \\
\hline & Mulberry tree & & Milk powder \\
\hline \multirow{3}{*}{ Tree Mix TX3 } & Cedar & & Casein \\
\hline & Cypress & \multirow{3}{*}{ Food Mix FX2 } & Chicken \\
\hline & Juniper/savin tree & & Lamb/mutton \\
\hline \multirow{3}{*}{ Weed Mix WX1 } & Hibiscus & & Pork \\
\hline & Rap & \multirow{4}{*}{ Food Mix FX3 } & Rice \\
\hline & Sorrel & & Potatoes \\
\hline \multirow{6}{*}{ Weed Mix WX2 } & Cocklebur & & Tomatoes \\
\hline & Sunflower & & Mustard \\
\hline & Chrysanthemum & \multirow{3}{*}{ Seafood Mix SX } & Crab \\
\hline & Wormwood & & Shrimp \\
\hline & $\begin{array}{l}\text { Ambrosia mugwort } \\
\text { leaved }\end{array}$ & & Haddock \\
\hline & \begin{tabular}{|l|} 
Mugwort \\
\end{tabular} & \multirow{3}{*}{ Nut Mix NX } & Cashew nuts \\
\hline \multirow{6}{*}{ Mite Mix DX1 } & Euroglyphusmaynei & & Coconuts \\
\hline & Dermatophagoidesfarine & & Peanuts \\
\hline & D. pterronysinnus & \multirow{3}{*}{ Fruit Mix RX1 } & Bananas \\
\hline & Tyrophagusputrescentiae & & Mango \\
\hline & \begin{tabular}{|l|} 
Glycophagus \\
\end{tabular} & & \begin{tabular}{|l|} 
Latex \\
\end{tabular} \\
\hline & \begin{tabular}{|l|} 
Cockroach \\
\end{tabular} & \multirow{4}{*}{ Fruit Mix RX2 } & Pineapple \\
\hline \multirow{5}{*}{ Epithelia Mix EX } & Cow, Cow epithelia & & Green apples \\
\hline & Dog Dog dander/epithelia & & Orange \\
\hline & $\begin{array}{l}\text { Mouse, Mouse dung/ } \\
\text { epithelia }\end{array}$ & & Grapefruit \\
\hline & Rat, Rat dander/ epithelia & \multirow{6}{*}{ Legume Mix LX } & Green beans \\
\hline & Cat, Cat dander/ epithelia & & Chick peas \\
\hline \multirow{4}{*}{ Insect Mix IX } & Bee venom & & Kidney beans \\
\hline & Wasp Venom & & \begin{tabular}{|l|} 
Lentils \\
\end{tabular} \\
\hline & Bumble bee venom & & Peas \\
\hline & Mosquito & & Soya Beans \\
\hline
\end{tabular}

Statistical Analysis:

Datas were compiled, entered and analysed using SPSS version 2.6. Continuous measures were expressed as means \pm standard deviations for normally distributed data and medians and percentiles for non-normally distributed datas. Descriptive statistics were used to describe demographic datas.

\section{RESULTS}

Demographic Data:

Three hundred and fourteen patients were included in the study with 56\% (175) being female and 44\% (139) being male with a female : male ratio of $1.2: 1$. The age of the patients ranged from 5years to 84 years with a mean of $37.33 \pm 14.39$ years. The duration of the disease also ranged from 0.15 to 20 years in which $116(36.9 \%)$ patients presented with disease of less than 6 months duration while 163(51.9\%) patients had the disease for more than 6 months. 
Alergy test result:

Among the 314 patients, 279(88.9\%) patients showed a positive test to the allergens whereas $35(11.1 \%)$ were negative to the test.

Among the people who tested positive for allergies, most were allergic to plants, of which weeds and grass were strongly allergic in 60 patients and slightly allergic in 92 patients. The allergic profile of the other allergens are shown in table 2 and Table 3 .

\section{DISCUSSION}

The prevalence of CU has been estimated to be around 0.5 $5 \%$. ${ }^{5,6} \mathrm{It}$ is a common cause of distress to many patients and can severely affect the quality of lives in some. However the cause cannot be always identified in individuals with $\mathrm{CU}$ and the relapse occurs when the drugs are discontinued by the physician and sometimes by the patient themselves. This study tried to find the common allergies if any using the serum test for standard provided allergens.

Our study also showed a female preponderance and a similar average age of the patients enrolled as reported by Vohra $\mathrm{S}$ all and Zhong et al ${ }^{7,8}$ The average duration of the disease is said to be $2-5$ years ${ }^{9}$ of which as reported by Gaig and Kozel et al, $70 \%$ of patients present with the disease duration of more than 6 months. Our study also showed the prevalence of more than $51.9 \%$ of patients with urtcaria of more than 1 year duration $^{10,11}$.

The factors that are reported to predict longer duration of the disease or the severity of the disease is very limited in the literature. The commonest implicated symptoms of food induced allergic reaction has been reported as urticariathough IgE-mediated food allergy is rarely the underlying cause of chronic spontaneous urticaria $^{12}$

The positive test showing allergens causing food allergy and urticaria was found in $232(73.8 \%)$ patients . The commonest reactions were to meat and sea food like crab, shrimp and haddock in 90 (28.66\%) patients followed by common foods like egg white, milk powder, chicken, pork and legumes etc in $89(28.3 \%)$ and fruit allergy to $53(16.8 \%)$ patients. Ninety five $(95.5 \%)$ of which showed slight allergy while $4.5 \%$ of the patients showed significant allergy.

Food allergy has been reported as $13.1 \%$ by Chung et al ${ }^{11}$ while a Chinese study reported a $22 \%$ positivity in the Ig E specific test ${ }^{14}$. Though the food tested were similar in both studies our study found a greater prevalence because of low availability and non sensitization of sea foods in a land locked country and hence more the allergic reaction.
Weeds and grass as a common allergen positivity was seen in $152(48.4 \%)$ patients out of which 60(39.4\%) patients showed a significant reaction. The commonest weeds that were tested in the panel were Mugwort,Chrysanthemum, Sunflower followed by the Bermuda Grass, Timothy grass and Orchard grass and others in the grass series.Mugwortand other members of the Compositae/Asteraceae family including chrysanthem have been studied for causing allergic reactions including urticaria. Similarly weed allergy has also been reported to have cross reactivity with other foods and fruits and thus can potentiate urticaria. De Vos G in his study has found $24 \%$ of patients with CU positive to mugwort . Other allergens showing cross reactivity was also found to be significant. ${ }^{15}$

Animals and insects allergen was positive in 145(46.1\%) patients. Amongst these 60(19.1\%) were strongly positive. The animals included dog,cow,rat,cat along with the mite mix containing glycophages and cockroaches. De Vos G has also found associations of indoor allergen sensitization (i.e. rat, cat and dust mite) with $\mathrm{CU} .^{15}$ It has been postulated that that the serum of patients with $\mathrm{CU}$ contains intrinsic factors that lead to mast cell degranulation through mechanisms that bypass the IgE receptor. ${ }^{16}$ Housedust mites (HDMs) and cockroaches are important sources of indoor allergens. Dermatophagoide spteronyssinus and its components have been studied to have allergenic properties in various allergic studies. ${ }^{17}$ Temperate Climate during the summer season, usage of carpets and keeping indoor pets in our studies points to the evidence of the above allergens in causing $\mathrm{CU}$.

Allergy to trees was found in $134(42.67 \%)$ patients and 35 $(26.11 \%)$ showed a severe positive reaction. The common tree antigens that were tested included birch, acacia, eucalyptus, cypress etc. The pollen season has been reported to have an increase in the rise of allergic diseases in many countries. Aeropollens could be one of the major causes of $\mathrm{CU}$ in our patients.

One hundred and thirty six (43.3\%) patients showed a positive test to mold allergy of which 5 (3.6\%) patients showed a strong correlation. In a study done by Bains and Dogra, Skin Prick Test positivity to molds in CU was seen in $12.2 \%{ }^{18}$ The evaluation however of the sensitivity to moulds is difficult because of their diversity, their uncertain regional distribution, and often prolonged period of exposure. ${ }^{19}$ Humid and often prolonged monsoon season in Nepal favours easy growth of molds both indoors and outdoors and often staying in less ventilated and dark rooms could favour the possibility of the urticaria in our patients. 


\section{CONCLUSION}

CU thus can be controlled not only by specific elimination of diets but also by environmental control measures to reduce exposure to indoor allergens which in turn will contribute to symptom improvement in sensitized CU patients.

\section{ACKNOWLEDGMENT:}

A special thanks to BioMED reference Laboratory for conducting the tests and providing us with the results.

\section{REFERENCES}

1. Zuberbier T,Bindslev-Jensen C, Canonica W et al. Definition, classification and diagnosis of urticaria. Allergy 2006; 61:316 $-20$

2. Najib U, Sheikh J. The spectrum of chronic urticaria. Allergy AsthmaProc 2009; 30:1-10.

3. Kaplan AP, Greaves M.Pathogenesis of chronic urticaria. ClinExpAllergy 2009;39:777-87.

4. Wedi B.Urticaria.JDtschDermatolGes 2008; 6:306-17

5. Bernstein JA, Lang DM, Khan DAet al. The diagnosisand management of acute and chronic urticaria: 2014 update. $J$ Allergy ClinImmunol2014;133:1270-7.

6. Vohra S, Sharma NL, Mahajan VK et al. Clinicoepidemiologic features of chronic urticaria in patients having positive versus negative autologous serumskin test: a study of 100 Indian patients. Indian J DermatolVenereolLeprolhospital-based multicenter epidemiological study. Allergy. 2014 Mar;69(3):359-64. doi: 10.1111/all.12338.

7. Greaves M. Chronic urticaria. J Allergy ClinImmunol 2000; 105:664-72.

8. Gaig P, Olona M, Muñoz Lejarazu D et al. Epidemiology of urticaria in Spain. J InvestigAllergolClinImmunol 2004; 14:214-20.

9. Kozel MM, Mekkes JR, Bossuyt PM et al. Natural course of physical and chronic urticaria and angioedema in 220 patients. JAm AcadDermatol 2001; 45:387-91.

10. Sicherer SH, Sampson HA. Food Allergy. J Allergy ClinImmunol 2010;125 (Suppl. 2):S116-25

11. Chung BY, Cho YS, Kim HO et al. Food Allergy in KoreanPatients with Chronic Urticaria.Ann Dermatol. 2016 Oct; 28(5):562-68

12. Hsu ML and Li LF.Prevalence of food avoidance and food allergy in Chinese patients with chronic urticaria..Br $J$ Dermatol. 2012 Apr; 166(4):747-52.
13. De Vos G, Kravvariti E, Collins J et al. Dermatology. 2012; 225(2):141-6. doi: 10.1159/000342356

14. Bossi F, Frossi B, Radillo O et al. Mast cells are critically involved in serum-mediated vascular leakage in chronic urticaria beyond high-affinity IgE receptor stimulation. Allergy 2011;66:1538-45.

15. Kim HS, Kang SH, Won S et al. Immunoglobulin E to allergen components of house dust mite in Korean children with allergic disease. Asia Pac Allergy 2015 Jul; 5(3):156-62.

16. Bains $P$, Dogra A. Skin prick test in patients with chronic allergic skin disorders.Indian J Dermatol. 2015 Mar-Apr; 60(2): 159-64.

17. Nath AK, Adityan B, Thappa DM. Prick testing in chronic idiopathic urticaria: A report from a tertiary care centre in south India. Int J Dermatol. 2008; 6:10 